\title{
Radiographic Assessment of Implant Failures of Titanium 3.5 LCP vs. 4.5 LCP Used for Flexible Bridging Osteosynthesis of Large Segmental Femoral Diaphyseal Defects in a Miniature Pig Model
}

\author{
Alois Nečas ${ }^{1}$, Pavel Proks ${ }^{2}$, Lucie Urbanová1, Robert Srnec ${ }^{1}$, Ladislav Stehlík ${ }^{2}$, Michal Crha ${ }^{1}$, \\ Petr Raušer ${ }^{1}$, Ladislav Plánka ${ }^{3}$, Evžen Amler ${ }^{4,5}$, Lucy Vojtová ${ }^{6}$, Josef Jančáŕ ${ }^{6}$ \\ ${ }^{1}$ Department of Surgery and Orthopaedics, Small Animal Clinic, Faculty of Veterinary Medicine, \\ University of Veterinary and Pharmaceutical Sciences, Brno, Czech Republic \\ ${ }^{2}$ Department of Diagnostic Imaging, Small Animal Clinic, Faculty of Veterinary Medicine, \\ University of Veterinary and Pharmaceutical Sciences, Brno, Czech Republic \\ ${ }^{3}$ Department of Pediatric Surgery, Orthopaedics and Traumatology, Faculty Hospital Brno, Czech Republic \\ ${ }^{4}$ Laboratory of Tissue Engineering, Institute of Experimental Medicine, Academy of Sciences \\ of the Czech Republic, v. v. i., Prague, Czech Republic \\ ${ }^{5}$ Institute of Biophysics, $2^{\text {nd }}$ Faculty of Medicine, Charles University in Prague, Prague, Czech Republic \\ ${ }^{6}$ Institute of Materials Chemistry, Brno University of Technology, Czech Republic
}

Received June 15, 2010

Accepted September 21, 2010

\begin{abstract}
The study describes types, absolute and relative numbers of implant failures in flexible bridging osteosynthesis using a six-hole $3.5 \mathrm{~mm}$ titanium Locking Compression Plate $(\mathrm{n}=9)$ or a fivehole LCP $4.5 \mathrm{~mm}$ titanium $(\mathrm{n}=40)$ selected for the fixation of segmental ostectomy of femoral diaphysis in the miniature pig used as an in vivo model in a study on the healing of a critically sized bone defect using transplantation of mesenchymal stem cells combined with biocompatible scaffolds within a broader research project.

Occasional implant failure was evaluated based on radiographic examination of femurs of animals 2, 4, 8, 12 and 16 weeks after surgery. When bone defect was stabilized using $3.5 \mathrm{~mm}$ LCP, in 6 cases $(66.7 \%)$ the screw was broken/lost in the proximal fragment of the femur 2 weeks after implantation $(n=4)$ and 4 weeks after implantation $(n=2)$. In 4 cases of these, the implant failure was accompanied also by loosening of the screw in position 3 in the proximal fragment of the femur. During ostectomy stabilization with $4.5 \mathrm{~mm} \mathrm{LCP}$, in 3 cases $(7.5 \%)$ LCP was broken at the place of the empty central plate hole (without inserted screw) at the level of the segmental bone defect.

Compared to the six-hole $3.5 \mathrm{~mm}$ LCP, the five-hole titanium $4.5 \mathrm{~mm}$ LCP is more suitable implant for flexible bridging osteosynthesis of a critically sized segmental defect of femoral diaphysis in the miniature pig. The results of this study will allow reducing implant failures in time- and cost-demanding transplantation experiments focused on bone healing.
\end{abstract}

Fracture fixation, bone healing, comminuted fracture, nonunion, ostectomy, buttress plate

Bone tissue is able to regenerate; however, the natural bone healing process might be in some cases insufficient. These include critically sized bone defects in the form of comminuted fractures, and ostectomies after excision of bone tumors (Kattapuram et al. 1989). Experimental removal of a larger bone segment imitates clinical conditions in comminuted fractures or in ostectomy during bone tumor removal.

In spite of increasing knowledge on bone healing in fractures and associated biomechanical aspects (Perren and Cordey 1980; Rahn 1982; O'Sullivan et al. 1989; Hulse et al. 1997; Hulse et al. 2000; Gautier and Sommer 2003; Wagner 2003; Aguila et al. 2005; Koch 2005; Tyler et al. 2008; Zahn et al. 2008; Filipowicz et al. 2009; Goh et al. 2009) and the increasing quality of bone implants, bone nonunion remains a frequent problem both in human and veterinary medicine (Lambiris et al. 2007). It is presumed that bone regeneration and successful bone defect healing may be supported by transplantation of mesenchymal stem cells in combination with biomaterials (Crha 2009; Nečas et al.

Address for correspondence:

Prof. MVDr. Alois Nečas, Ph.D., MBA

Department of Surgery and Orthopaedics

Small Animal Clinic, Faculty of Veterinary Medicine

University of Veterinary and Pharmaceutical Sciences Brno

Palackeho 1-3, 61242 Brno, Czech Republic

Phone: +420541562344

Fax: +420541562 344

E-mail: necas@eurosat.cz

http://www.vfu.cz/acta-vet/actavet.htm 
2009). A model of nonunion with the application of stem cells was experimentally studied in rats (Lee et al. 1994; Stevanson et al. 1994; Wolff et al. 1994; Werntz et al. 1996; Kadiyala et al. 1997; Russell et al. 2007), rabbits (Kirker-Head et al. 2007), sheep (Gerhart et al. 1993; Kon et al. 2000; Schmidhammer et al. 2006) and dogs (Delloye et al. 1992; Volpon 1994; Kraus et al. 1999). To our knowledge, this subject has not been studied in miniature pigs so far.

As regards fracture stabilization and elimination of forces acting in the fracture line, in some fractures anatomical reduction is not possible (comminuted fractures), due to the loss of continuity of bone column. In these cases osteosynthesis with bridging (buttress) plate is usually used (Piermattei and Flo 1997; Koch 2005; Nečas et al. 2007). In this type of fixation, the plate ensures maintaining the appropriate bone length and the correct axial orientation of its main fragments and the appropriate spatial alignment of the joints proximally and distally from the fracture site. The function of the bridging plate is to prevent undesirable dislocation of bone fragments caused by shearing and bending forces in the fracture line (Piermattei and Flo 1997; Koch 2005; Nečas et al. 2007). When a bridging plate is used, the whole transfer of acting forces loads the implant until a bone callus is formed, capable of carrying part of the load (Piermattei and Flo 1997; Koch 2005; Nečas et al. 2007). Especially this phase of fracture healing is critical regarding possible implant failure due to the insufficiency to withstand all the acting forces of the load, which to this day have not been accurately described in animals.

To our knowledge, the healing of segmental defects of femoral diaphysis stabilized by flexible bridging osteosynthesis (Wagner et al. 2003) using titanium locking compression plate (LCP) has not been described so far in miniature pigs as experimental model animals, and the occurrence of possible complications with regard to LCP implant failure has not been studied. The miniature pig serves as animal model in an experimental in vivo study of the healing of a critically sized segmental bone defect using the transplantation of mesenchymal stem cells combined with biocompatible scaffolds within the research project NPV II 2B06130.

The aim of this study was to radiographically assess the types of failure of flexible bridging osteosynthesis with two dimensionally different implants, a six-hole $3.5 \mathrm{~mm}$ titanium LCP and a five-hole $4.5 \mathrm{~mm}$ titanium LCP for fixation of segmental ostectomy of femoral diaphysis in miniature pigs, and to determine the absolute and relative numbers of implant failures. Another aim of this pilot study was to verify in vivo whether for fixation of the above mentioned segmental bone defect the less robust six-hole $3.5 \mathrm{~mm}$ LCP with four $3.5 \mathrm{~mm}$ screw inserted over the plate or the more robust $4.5 \mathrm{~mm}$ LCP with four $4.5 \mathrm{~mm}$ screws is more suitable. Considering the shape and size of the femur of the chosen animal model, these two options were the only applicable sizes of locking compression plates. The expected output was that the findings would allow to determine a more suitable size of LCP implants for the miniature pig model used for prospective transplantation experiments within the research plan NPV II 2B06130 in the form of implantation of mesenchymal stem cells (MSCs) combined with biomaterials (scaffolds) into segmental femoral defects, and thereby to prevent the possibility of potential undesirable implant failure in such material-, time- and cost-demanding project.

\section{Materials and Methods}

A total of 49 miniature pigs were included in the study of bone defect healing. The mean body weight of the animals at the time of inclusion in the study was $18.60 \mathrm{~kg}( \pm 5.17)$ within the range of $18.60-29.00 \mathrm{~kg}$. The mean age at the time of inclusion in the study was 21.6 weeks $( \pm 3.05)$ within the range of $15-32$ weeks. The study included 33 males and 16 females. In this miniature pig model $(n=49)$ from certified breeding of the Academy of Sciences in Liběchov, Czech Republic, an iatrogenic segmental bone defect (ostectomy) was created in the centre of the diaphysis of the left femur. Segmental bone defect was created with oscillating saw in the whole cross section of the bone at the height of $15 \mathrm{~mm}$ of the bone column. While maintaining the principles of flexible 
bridging osteosynthesis (Stoffel et al. 2000; Stoffel et al. 2003; Wagner 2003), the main femoral fragments of the miniature pigs were stabilized using one of the two dimensionally relevant (with regard to the dimensions and size of the bone of the animals used) systems of LCP. Six-hole titanium locking compression plate (LCP, Synthes $\left.^{\mathbb{B}}\right)$ in the system of $3.5 \mathrm{~mm}(\mathrm{n}=9)$ and four $3.5 \mathrm{~mm}$ titanium locking bicortical screws leaving two central plate holes empty at the level of the segmental bone defect was used (Plate V, Fig. 1). Alternately, a five-hole titanium LCP (Synthes $\left.{ }^{\circledR}\right)$ in the system of $4.5 \mathrm{~mm}(\mathrm{n}=40)$ and four $4.5 \mathrm{~mm}$ titanium locking bicortical screws leaving one empty central plate hole at the level of the segmental bone defect were used (Fig. 2).

In all cases stabilized with the system of $3.5(n=9)$, the ostectomy defect was left without filling. In cases fixated in the system of $4.5(\mathrm{n}=40)$, the defect was left without filling in 4 animals. In 7 animals the segmental bone defect was filled with autogenous cancellous bone graft taken from tuberculum majus humeri of the left humerus. In 5 animals the segmental bone defect was filled with resorbable nanocomposite scaffold from hydroxyapatite (HAP) and $0.5 \%$ collagen (1:1). In 7 animals the segmental bone defect was filled with resorbable nanocomposite scaffold from hydroxyapatite (HAP) and $\%$ collagen (1:1). In 4 animals the iatrogenic femoral defect was filled with the same scaffold from HAP and $2 \%$ collagen $(1: 1)$ seeded with mesenchymal stem cells (MSCs). In 4 animals the iatrogenic femoral defect was filled with a multilayer scaffold from HAP and $2 \%$ collagen (1:1). In 4 animals the iatrogenic femoral defect was filled with the scaffold Chronos (Synthes ${ }^{\mathbb{R}}$ ) and in 5 animals the iatrogenic femoral defect was filled with the scaffold Chronos (Synthes ${ }^{\sqrt{\mathbb{R}}}$ ) seeded with mesenchymal stem cells.

Radiographic examination was done immediately after the surgical procedure and X-ray check-ups of the healing of the segmental bone defect were done 2, 4, 8, 12 and 16 weeks after creating the bone defect. Mediolateral $(\mathrm{ML})$ and craniocaudal $(\mathrm{CrCd})$ projections were made. Animals were euthanised 16 weeks after operation. Subsequently, radiographs of the femurs with implants in ML and CrCd projections were made. The surgical procedures including appropriate postoperative care and check-up X-ray examinations were performed in complete accordance with the ethical regulations for animal experiments.

From the radiographs of the femurs, complications of fracture healing in the form of possible implant failure were evaluated during each check-up. Observations were done on digital radiographs (CR Capsula XL/Fuji) in the program JiveX (Visus-Technology Transfer $\mathrm{GmbH}$ ). We evaluated the number of failures of fixation of the segmental osteotomy of the femur by flexible bridging osteosynthesis using both 3.5 and 4.5 LCP systems. We evaluated the collapse of fracture line, the number and positions of broken screws inserted through the holes in the plate or the bending and loosening of the screws, and the difference in the occurrence of implant failure for the six-hole $3.5 \mathrm{~mm}$ titanium LCP and for the five-hole $4.5 \mathrm{~mm}$ titanium LCP.

For statistical analysis of the data, Wilcoxon (Mann-Whitney) test for unpaired data was used. Null hypothesis presumed that there would be no significant difference in the frequency of implant failures between the group of pigs treated with the six-hole $3.5 \mathrm{~mm}$ titanium LCP $\left(\right.$ Synthes $^{\circledR}$ ) and the five-hole $4.5 \mathrm{~mm}$ titanium LCP $\left(\right.$ Synthes $\left.{ }^{\circledR}\right)$.

\section{Results}

No significant difference in sex, body weight and age of the animals included in the study $(p>0.05)$ was found between the groups of miniature pigs treated with the six-hole $3.5 \mathrm{~mm}$ titanium LCP $\left(\right.$ Synthes $^{\circledR}$ ) and the five-hole $4.5 \mathrm{~mm}$ titanium LCP $\left(\right.$ Synthes $\left.^{\circledR}\right)$.

Titanium locking screws were broken in the group of pigs treated with the six-hole $3.5 \mathrm{~mm}$ titanium LCP $\left(\right.$ Synthes $^{\circledR}$ ) in $66.7 \%$ cases $(6 / 9)$. In four cases, a broken screw was noted during an X-ray check-up 2 weeks after surgery; in two cases 4 weeks after surgery. In all cases it was the screw in position 2 in the proximal fragment of the femur (Plate VI, Fig. 3). In 4 cases the breaking of the titanium screws was accompanied by loosening of screws in position 3 of the proximal bone segment and a collapse of the segmental ostectomy defect with dislocation of the proximal fragment of the femur distally (Fig. 3). In the group of pigs with femoral osteotomy fixated with a five-hole $4.5 \mathrm{~mm}$ titanium LCP (Synthes ${ }^{\mathbb{B}}$ ) the titanium locking screws were broken in $15 \%$ cases (6/40). In 3 cases the broken screw was noted during the X-ray check-up 4 weeks after surgery; in three cases 12 weeks after surgery. No breaking of the $4.5 \mathrm{~mm}$ titanium locking screw accompanied by loosening of another screw or a collapse of the ostectomy defect was recorded. In the group of miniature pigs with segmental femoral ostectomy fixated with the six-hole $3.5 \mathrm{~mm}$ titanium LCP, a significant difference was found $(p<0.01)$ in the number of failures of titanium locking screws compared to the group of pigs treated with the five-hole $4.5 \mathrm{~mm}$ titanium LCP.

In the group of pigs treated with the six-hole $3.5 \mathrm{~mm}$ titanium LCP, no case of LCP breaking was noted. In the group of pigs treated with the five-hole $4.5 \mathrm{~mm}$ titanium LCP the breaking of LCP was noted in $7.5 \%$ cases (3/40). In all cases the LCP was broken at the level of the 
central empty hole (without screw), at the place of the segmental bone defect (Plate VI, Fig. 4). In one case a broken LCP was found during the X-ray check-up fourth week after surgery (nanocomposite scaffold from hydroxyapatite and $2 \%$ collagen $1: 1$ ). In 2 cases a broken LCP was found in week 16 after surgery (nanocomposite scaffold from hydroxyapatite and 2\% collagen 1:1, Chronos seeded with MSCs). In all 3 cases, symptoms of bone healing in the form of bone callus formation were not found at the time of finding the implant failure in

Table 1. Complications in form of LCP implant failure during fixation of segmental ostectomy of the femur in miniature pigs.

\begin{tabular}{|c|c|c|c|}
\hline \multicolumn{5}{|c|}{ Six-hole 3.5 mm LCP (n =9) } \\
\hline Weeks after surgery & Broken LCP & Broken screw & Lost screw \\
\hline 2 & 0 & 4 & 3 \\
\hline 4 & 0 & 2 & 1 \\
\hline 8 & 0 & 0 & 0 \\
\hline 12 & 0 & 0 & 0 \\
\hline 16 & 0 & 0 & 0 \\
\hline $\begin{array}{l}\text { Total number of } \\
\text { implant failures }\end{array}$ & 0 & $6^{*}$ & 4 \\
\hline \multicolumn{4}{|c|}{ Five-hole 4.5 mm LCP (n = 40) } \\
\hline Weeks after surgery & Broken LCP & Broken screw & Lost screw \\
\hline 2 & 0 & 0 & 0 \\
\hline 4 & 1 & 3 & 0 \\
\hline 8 & 0 & 0 & 0 \\
\hline 12 & 2 & 3 & 0 \\
\hline 16 & 0 & 0 & 0 \\
\hline $\begin{array}{l}\text { Total number of } \\
\text { implant failures }\end{array}$ & 3 & $6 *$ & 0 \\
\hline
\end{tabular}

$* p<0.01$ the form of broken LCP. No significant difference was found $(p>0.05)$ between the failure of the six-hole $3.5 \mathrm{~mm}$ titanium LCP and the five-hole $4.5 \mathrm{~mm}$ titanium LCP.

Regarding the total number of implant failures (LCP breaking, titanium locking screw failure), a significantly higher number of implant failures was found in the group of pigs treated with the six-hole $3.5 \mathrm{~mm}$ titanium LCP $(p<0.05)$ than in the pigs treated with the five-hole $4.5 \mathrm{~mm}$ titanium LCP. Complications of implant failure during fixation of segmental femoral ostectomy using flexible bridging osteosynthesis with LCP implants are summarized in Table 1.

\section{Discussion}

The miniature pig is frequently used as model animal especially for surgical experiments (Swindle 2007). As opposed to laboratory experimental animals (rat, rabbit), pig femur is much better comparable with its size to the size of human long bones. Stability and resistance of the fixation apparatus at the breaking site against acting forces is especially important in the research of fracture healing because movement activity often cannot be prevented in experimental animals. In the initial phase of bone healing, compression, bending and torsion forces as well as their mutual combination act on the site of defect. The adverse acting of these forces may be reduced by using bone implants (Perren 1991).

In the course of our study the titanium locking screw was broken in a total of 12 cases. Of these, 6 cases $(6 / 9)$ were found in miniature pigs treated with the six-hole $3.5 \mathrm{~mm}$ titanium LCP and $6(6 / 40)$ in pigs with segmental ostectomy fixated by the five-hole $4.5 \mathrm{~mm}$ titanium LCP. In the group of segmental ostectomy treated by fixation using the six-hole $3.5 \mathrm{~mm}$ titanium LCP a highly significant $(p<0.01)$ number of titanium locking screw failures was found compared to the group of pigs treated with the five-hole $4.5 \mathrm{~mm}$ titanium LCP. The number of cortical screws affects the implant stability (Piermattei and Flo 1997; Stoffel et al. 2000; Stoffel et al. 2003; Wagner 2003; Koch 2005; Nečas et al. 2007). In flexible bridging osteosynthesis using LCP, more than 3 cortical screws inserted in one bone fragment only slightly increase the axial stability (rigidity) of fixation (S toffel et al. 2003). At the same time, the closer to the breaking line the cortical screws are inserted, the higher stability against compression forces is shown by LCP (Stoffel at al. 2003). In our study we found in 4 cases out of 6 a broken cortical screw in position 2 in the 
proximal fragment of the femur during the X-ray check-up 2 weeks after surgery, and in 2 cases a broken screw in the same position 4 weeks after surgery, i.e. in the initial phase of ostectomy defect healing.

The cortical screw in position 2 in the proximal segment of the bone is exposed to the highest shearing forces (Stoffel et al. 2003). Cortical screw in position 3 in the proximal segment of the femur was lost and dislocated probably as a result of the contraction forces acting on the implant. This caused the screw in position 3 to tear out of the bone (overload at places of contact of the screw with the bone) leading subsequently to the collapse of the ostectomy defect.

All cases of broken LCP occurred in the group of pigs with ostectomy of the femur fixated using the five-hole $4.5 \mathrm{~mm}$ titanium LCP. With the use of LCP for fixation of a critically sized diaphyseal defect, bending forces act in the absence of cortical bone on the opposed side which may lead to fixation failure in the form of bending or breaking of the bone plate (Hulse et al. 1997). The cause of the described failure (breaking of the plate at the place of the empty central plate hole) of $4.5 \mathrm{~mm}$ LCP in the bridging fixation of segmental femoral osteotomy in the miniature pig as model animal was probably the concentration of bending forces at the place of the hollow opening (unfilled with screw) at the site of the ostectomy defect (Stoffel et al. 2000; Stoffel et al. 2003). With regard to time, the first weeks after segmental defect fixation present the highest risk of possible LCP implant failure, i.e. the time before bone callus formation (Bernarde at al. 2001). Surprisingly, in 2 of 3 cases the breaking of LCP was noted only during the X-ray check-up in week 16 after surgery, i.e. any time during week 12-16 after the insertion of implants, i.e. at the time of expected fibrous and bone callus formation. However, in all cases, formation of bone callus was not found radiologically at the time of finding the broken LCP; and in two cases of broken LCP found during the last X-ray check-up in week 16, the bone defect healing could be classified as atrophic nonunion. In the group of miniature pigs with segmental defect of femoral diaphysis fixated using the six-hole $3.5 \mathrm{~mm}$ titanium LCP $(\mathrm{n}=9)$ we found no case of bone plate breaking. A longer bone plate is generally more suitable because forces are more distributed; there is less tension at the place of absent bone (Rozbruch et al. 1998; Stoffel et al. 2003) because concentration of bending forces is prevented at the site of the hollow opening (unfilled with screw) of the plate. The size (robustness) of the bone plate that may be used in given case for fixation, however, tends to be limited by the size of the experimental animal, while a suitable alternative appears to be the use of larger-sized bone plates (Bernarde et al 2001). Although we found 3 cases of bone plate breaking in the group of pigs with segmental femoral osteotomy fixated using the five-hole $4.5 \mathrm{~mm}$ titanium LCP, we did not find a significant difference in the occurrence of fixation failure in the form of broken LCP compared to the group of animals with the bone defect stabilized using the six-hole $3.5 \mathrm{~mm}$ LCP. The result may be partly affected also by the smaller number of cases in the group of miniature pigs treated using the six-hole $3.5 \mathrm{~mm}$ titanium LCP.

With regard to the total number of implant failures (LCP breaking and titanium locking screw failure) we found a significantly higher number of implant failures in the group of pigs treated with the six-hole $4.5 \mathrm{~mm}$ titanium LCP than in the pigs treated with the five-hole $4.5 \mathrm{~mm}$ titanium LCP $(p<0.05)$. Fixation stability and implant resistance especially against the acting of torsion and compression forces are affected by a number of factors. Mainly, it is the length of the bone plate used, the distance of the first screw in the proximal and distal fragment which is the closest to the ostectomy defect (position 2) and the distance of the LCP itself from the bone cortex surface. It is known that in case of such large segmental defects of diaphysis or non-reducible comminuted fractures the fixation becomes more rigid the closer the mentioned screw is to the breaking line and the closer the plate is placed to the cortex surface (Stoffel et al. 2003). A short LCP with a sufficient number of cortical screws does have sufficient axial stability but it does not provide sufficient resistance against torsion forces of the load (Stoffel at al. 2003). 
Based on the results of our study, the five-hole $4.5 \mathrm{~mm}$ titanium LCP may be recommended as flexible bridging osteosynthesis for fixating segmental femoral defects on the model of miniature pigs. Although we did not prove a significant difference in the occurrence of implant failure between the group of pigs treated with the six-hole $3.5 \mathrm{~mm}$ titanium LCP and the group of pigs treated with the five-hole $4.5 \mathrm{~mm}$ titanium LCP, the breaking of the five-hole $4.5 \mathrm{~mm}$ titanium LCP occurred in three cases. Rigidity of the fixation apparatus could be increased e.g. by using the method of "plate and rod". The "plate and rod" method is significantly more rigid type of fracture fixation than a plate alone with the bridging function. The probability of a failure of the plate alone compared to fixation by the "plate and rod" combination is ten times higher (Hulse et al. 1997). For this reason, it is desirable to verify in the future on the experimental model of miniature pig that we use the suitability of the $4.5 \mathrm{~mm}$ LCP combined with the intramedular rod ("plate and rod" method) for fixation of a critically sized segmental defect of femoral diaphysis, and to determine possible types and frequencies of prospective fixation failures.

The results found in our study may be partly limited by the lower number of segmental ostectomies in the group of pigs treated with the six-hole $3.5 \mathrm{~mm}$ titanium LCP compared to the number of pigs treated with the five-hole $4.5 \mathrm{~mm}$ titanium LCP. Another possible limitation of the results of the study may be the comparison of the homogenous group of segmental ostectomies without filling by the cancellous bone graft or scaffold with a larger, less homogenous group of ostectomies left in some cases without filling, in other cases filled with scaffolds alone or with scaffolds with stem cells. However, this influence on results may be considered minimal because neither the cancellous bone graft nor any of the scaffolds we use show real bearing function from the viewpoint of transfer of forces. Possible speeding up of healing of the segmental defect filled with stem cells could lead to the lower number of implant failures in the group of pigs treated with the five-hole $4.5 \mathrm{~mm}$ titanium LCP, especially in the later phase of the experiment.

Even with regard to the above mentioned aspects it may be concluded that the five-hole titanium $4.5 \mathrm{~mm}$ LCP compared to the six-hole $3.5 \mathrm{~mm}$ LCP appears to be a more suitable implant for performing flexible bridging osteosynthesis of a critically sized segmental defect of femoral diaphysis in the miniature pig as animal experimental model.

The results of this study allow reducing prospective undesirable implant failures in timeand cost-demanding transplantation experiments focused on bone healing.

\section{Rentgenologické hodnocení selhání implantátů při použití flexibilní pilířové osteosyntézy titanovou 3,5 LCP vs. 4,5 LCP k fixaci velkého segmentálního defektu diafýzy femuru u miniaturního prasete jako modelového zvířete}

Ve studii jsou popsány typy, absolutní a relativní četnosti selhání implantátů při flexibilní pilírové osteosyntéze šestiděrovou $3,5 \mathrm{~mm}$ titanovou $\mathrm{LCP}(\mathrm{n}=9)$ a pětiděrovou 4,5 mm titanovou LCP $(\mathrm{n}=40)$, zvolené k fixaci segmentální ostektomie diafýzy femuru u miniaturního prasete, použitého jako in vivo model. ve studii hojení velkého segmentálního defektu kosti pomocí transplantace mezenchymových kmenových buněk v kombinaci s biokompatibilními skafoldy v rámci širšího výzkumného projektu.

Selhání implantátů bylo hodnoceno na základě rtg vyšetření femurů zvířat za $2,4,8$, 12 a 16 týdnů po operaci. V př́padě fixace defektu kosti $3,5 \mathrm{~mm}$ LCP došlo v 6 př́padech $(66,7 \%)$ ke zlomení/uvolnění šroubu v pozici $2 \mathrm{v}$ proximálním fragmentu femuru, a to za 2 týdny po implantaci $(n=4)$ a za 4 týdny po implantaci $(n=2)$. V 4 prípadech bylo selhání implantátu doprovázeno také uvolněním šroubu v pozici $3 \mathrm{v}$ proximálním fragmentu femuru. Při stabilizaci ostektomie $4,5 \mathrm{~mm}$ LCP došlo ve 3 př́padech $(7,5 \%)$ ke zlomení LCP v místě prázdného (šroubem nevyplněného) centrálního otvoru ploténky 
v úrovni segmentálního defektu kosti. Pětiděrová titanová 4,5 mm LCP se v porovnání $\mathrm{s}$ šestiděrovou 3,5 mm LCP jeví jako vhodnější implantát k provedení flexibilní pilírové osteosyntézy velkého segmentálního defektu diafýzy femuru u miniaturního prasete jako zvířecího experimentálního modelu. Výsledky této studie umožní omezit nežádoucí selhání implantátů při časově a finančně náročných transplantačních experimentech zaměřených na hojení kostí.

\section{Acknowledgement}

This work was supported by the Ministry of Education, Youth and Sports of the Czech Republic (Research Project NPV II 2B06130).

\section{References}

Aguila AZ, Manos JM, Orlansky AS, Todhunter RJ, Trotter EJ, van der Meulen MCH 2005: In vitro biomechanical comparison of limited contact dynamic compression plate and locking compression plate. Vet Comp Orthop Traumatol 18: 220-226

Bernarde A, Diop A, Maurel N, Viguier E 2001: An in vitro biomechanical study of bone plate and interlocking nail in a canine diaphyseal femoral fracture model. Vet Surg 30: 397-408

Crha M, Nečas A, Srnec R, Janovec J, Stehlík L, Raušer P, Urbanová L, Plánka L, Jančář J, Amler J 2009: Mesenchymal stem cells in bone tissue regeneration and application to bone healing. Acta Vet Brno 78: $635-645$

Delloye C, Verhelpen M, D'Hemncourt J, Govaerts B, Bourgois R 1992: Morphometric and physical investigations of segmental cortical bone autografts and allografts in canine ulnar defects. Clin Orthop Relat Res 282: $273-292$

Filipowicz D, Lanz O, McLaughlin R, Elder S, Werre S 2009: A biomechanice comparison of 3,5 locking compression plate fixation to 3,5 limited contact dynamic compression plate fixation in a canine cadaveric distal humeral metaphyseal gap model. Vet Comp Orthop Traumatol.22: 270-277

Gautier E, Sommer C. 2003: Guidelines for the clinical application of the LCP. Injury 34: S-B63-S-B76

Gerhart TN, Kirker-Head CA, Kriz ML, Holtrop ME, Henning GE, Hipp J, Schelling SH, Wang E 1993: Healing segmental femoral defects in sheep using recombinant human bone morphogenetic protein. 293: $317-326$

Goh CS, Santoni BG, Puttlitz CHM, Palmer RH 2009: Comparison of the mechanical behaviors of semiconttoured, locking plate-rod fixation and anatomically contoured, conventional plate- rod fixation applied to experimentally induced gap fractures in canine femora. Am J Vet Res 70: 23-29

Hulse D, Ferry K, Fawcett A, Gentry D, Hyman W, Geller S, Slater M. 2000: Effect of intramedullary pin size on reducing bone plate strain. Vet Comp Orthop Traumatol 13: 185-190

Hulse D, Hyman W, Nori M, Slater M 1997: Reduction in plate strain by addition of an intramedullary pin. Vet Surg 26: 451-459

Kadiyala S, Jaiswal N, Bruder SP 1997: Culture-expanded, bone marrow-derived mesenchymal stem cells can regenerate a critical-sized segmental bone defect. Tissue Eng 3: 173-185

Kattapuram VS, Philips WC, Mankin HJ 1989: Intercalary bone allografts: Radiographic evaluation. Radiology 170: $137-141$

Kirker-Head C, Karageorgiou V, Hofmann S, Fajardo R, Betz O, Merkle HP, Hilbe M, von Rechenberg B, McCool J, Abrahamsen L, Nazarian A, Cory E, Curtis M, Kaplan D, Meinel L 2007: BMP-silk composite matrices heal critically sized femoral defects. Bone 41: 247-255

Koch D 2005: Screws and plates. In: AO Principles of Fracture Management in the Dog and Cat. AO Publishing, Switzerland, pp. 26-50

Kon E, Muraglia A, Corsi A, Bianco P, Marcacci M, Martin I, Boyde A, Ruspantini I, Chistolini P, Rocca M, Giardino R, Cancedda R, Quarto R 2000: Autologous bone marrow stromal cells loaded onto porous hydroxyapatite ceramic accelerate bone repair in critical-size defects of sheep long bones. J Biomed Mater Res 49: 328-337

Kraus KH, Kadiyala S, Wotton H, Kurth A, Shea M, Hannan M, Hayes WC, Kirker-Head CA, Bruder S 1999: Critically sized osteo-periostal femoral defects: a dog model. J Invest Surg 12: 115-124

Lambiris E, Panagopoulos A, Zouboulis P, Sourgiadaki E 2007: Current concepts: Aseptic nonunion of femoral shaft diaphysis. Eur J Trauma Emerg Surg 2: 120-134

Lee SC, Shea M, Battle MA, Kozitza K, Ron E, Turek T, Schaub RG,.Hays WC 1994: Healing of large segmental defects in rat femur is aided by RhBMP-2 in PLGA matrix. J Biomed Mater Res 28: 1149-1156

Nečas A, Urbanová L, Srnec R 2007: Principy použití LCP plotének. In: Nečas A, Beale BS, Hulse DA, Srnec R a kol.: Osteotomie a nové trendy v léčbě nemocí kostí a kloubů. VFU Brno, pp. 19-22

Nečas A, Proks P, Srnec R, Stehlík L, Urbanová L, Crha M, Raušer P, Janovec J, DvořákV M 2009: Současné trendy v chirurgické léčbě segmentálních fraktur (MIPO, LCP, biomateriály). In Zborník príspevkov z odbornej konferencie „Škola, veda, prax II.“, Košice, Slovenská republika: UVL Košice, pp. 123-127 
O’Sullivan ME, Chao YS, Kelly PJ 1989: The effects of fixation on fracture-healing. J Bone Joint Surg Am 71: $306-310$

Perren SM 1991: The concept of biological plating using the limited contact dynamic compression plate (LCDCP) - Scientific background, design and application. Injury 22: 1-41

Perren SM, Cordey J 1980: The concept of interfragmentary strain. In: Uhthoff HK: Current Concepts of Internal Fixation of Fractures. Berlin Heidelberg New York: Springer-Verlag, p. 63.

Piermattei DL, Flo GL 1997: Brinker, Piermattei, and Flo's Handbook of Small Animal Orthopedics and Fracture Repair, 3rd ed., Philadelphia, WB Saunders, pp. 24-146

Rahn BA 1982: Bone healing:histologic and physiologic concepts. In: Summer-Smith G: Bone in Clinical Orthopaedics. Philadelphia, WB Saunders, pp. 335-386

Rozbruch SR, Muller U, Gautier E, Ganz R 1998: The evolution of femoral shaft plating technique. Clin Orthop 354: $195-208$

Russell G, Tucci M, Conflitti J, Graves M, Wingerter S, Woodall J, Ragab A 2007: Characterization of a femoral segmental nonunion model in laboratory rats: report of a novel surgical technique. J Invest Surg 20: 249-255

Schmidhammer R, Zandieh S, Mittermayer R, Pelinka LE, Lexnering M, Hopf R, Kroepfl A, Redl H 2006 : Assessement of bone union/nonunion in an experimental model using microcomputed technology. J Trauma 61: $199-205$

Stevanson S, Cunningham NS, Toth J, Davy D, Reddi AH 1994: The effect of osteogenin (a bone morphogenic protein) on the formation of bone in orthotopic segmental defects in rats. J Bone Joint Surg 76A: 1676-1687

Stoffel K, Dieter U, Stachowiak G, Gächter A, Kuster MS 2003: Biomechanical testing of the LCP - how can stability in locked internal fixators be controlled? Injury Int J Care Injured 34: S-B11-S-B19

Stoffel K, Klaue K, Perren SM 2000: Functional load of plates in fracture fixation in vivo and its correlate in bone healing. Injury Int J Care Injured 31: S-B37-S-B50

Swindle MM 2007: Swine in the laboratory, surgery, anesthesia, imaging, and experimental techniques, 2nd ed., Taylor \& Francis Group, Boca Raton, $471 \mathrm{p}$.

Tyler JM, Larinde W, Elder SH 2008: A device for performing whole bone torsional testing in a single-axis linear motion testing machine. Vet Comp Orthop Traumatol 21: 478-480

Volpon JB 1994: Nonunion using a canine model. Arch Orthop Trauma Surg. 113: 312-317

Wagner M 2003: General principles for the clinical use of the LCP. Injury Int J Care Injured 34: S-B31-S-B42

Werntz JR, Lane JM, Burstein AH, Justin R, Klein R, Tomin E 1996: Qualitative and quantitative analysis of orthotopic bone regeneration by marrow. J Orthop Res 14: 85-93

Wolff D, Goldberg VM, Stevenson S 1994: Histomorphometric analysis of the repair of a segmental diaphyseal defect with ceramic and titanium fibermetal implants: Effects of bone marrow. J Orthop Res. 12: 439-446

Zahn K, Frei R, Wunderle D, Linke B, Schwieger K, Guerguiev B, Pohler O, Matis U 2008: Mechanical properties of 18 different $\mathrm{AO}$ bone plates and the clamp-rod internal fixation system tested on a gap model construct. Vet Comp Orthop Traumatol 21: 185-194 
Plate V

Nečas A. et al.: Radiographic ... pp. 599-606

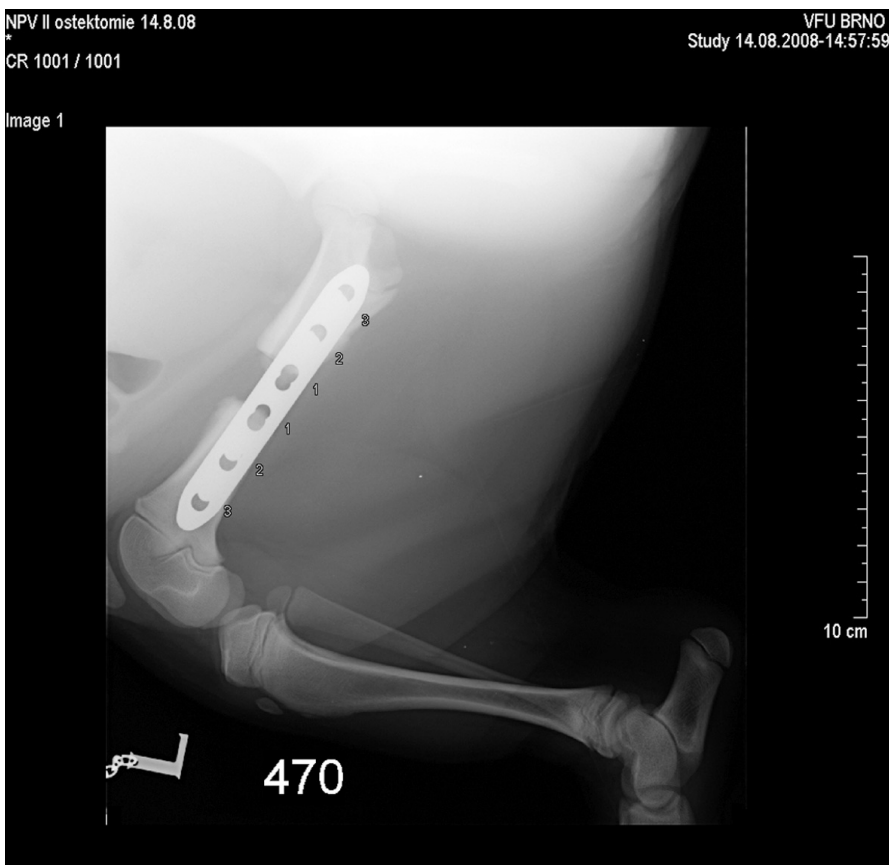

Fig. 1. Radiograph of the segmental femoral defect stabilized with the six-hole $3.5 \mathrm{~mm}$ LCP. Numbers identify positions of individual screws in the proximal and distal bone segments.

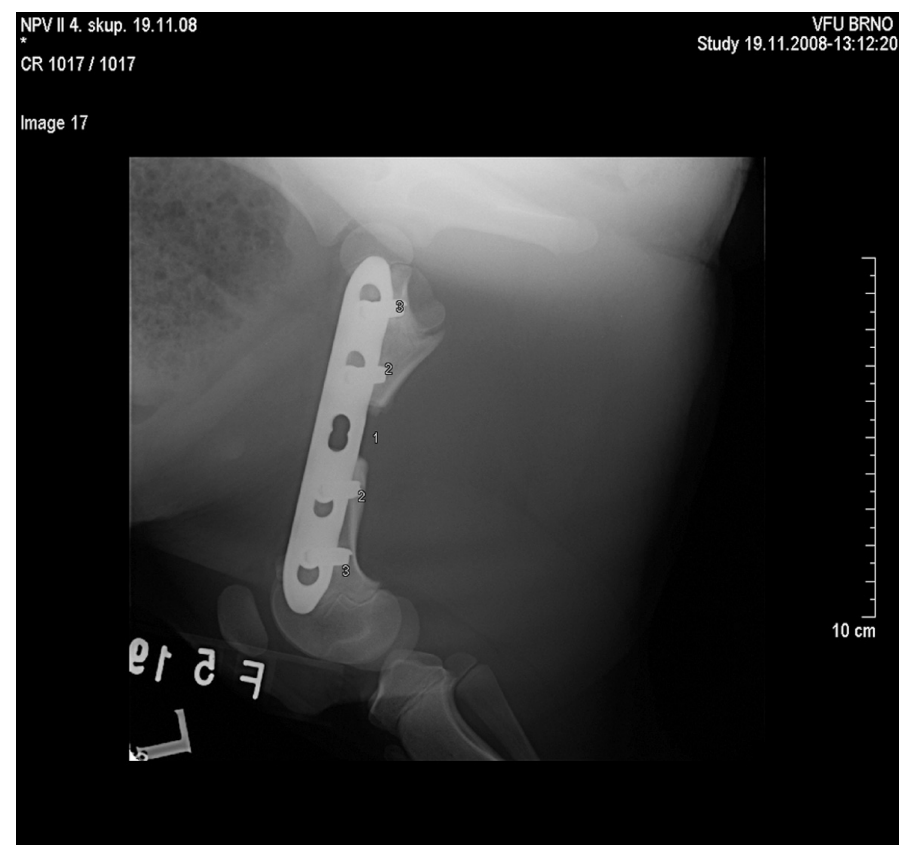

Fig. 2. Radiograph of the segmental femoral defect stabilized with the five-hole $4.5 \mathrm{~mm}$ LCP. Numbers identify positions of individual screws in the proximal and distal bone segments. 
Plate VI

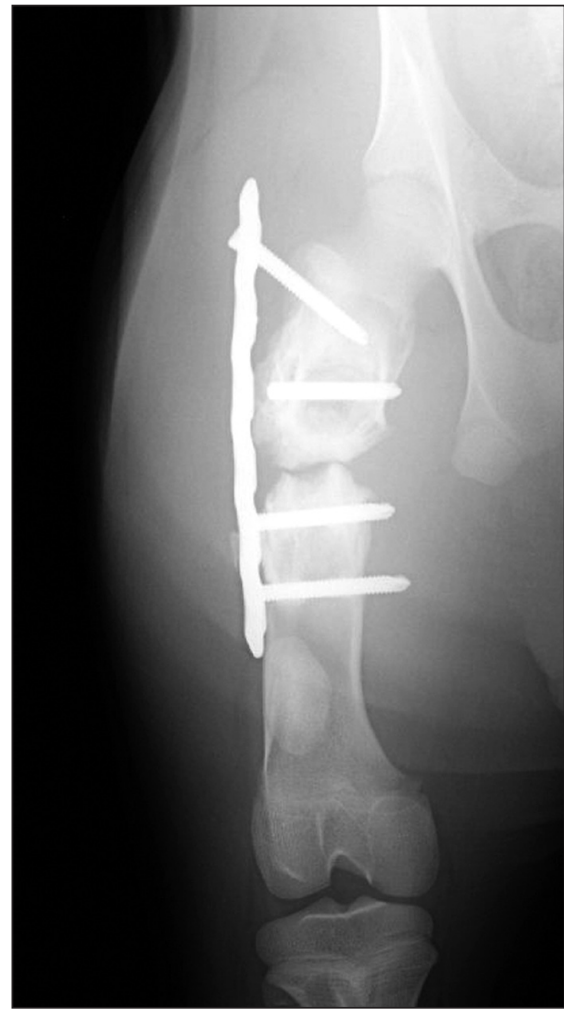

Fig. 3. Fixation of the segmental femoral defect with $3.5 \mathrm{~mm}$ LCP. Broken screw in position 2 in the proximal femoral fragment is accompanied by lost screw in position 3 and collapse of fracture line ( 2 weeks after surgery).

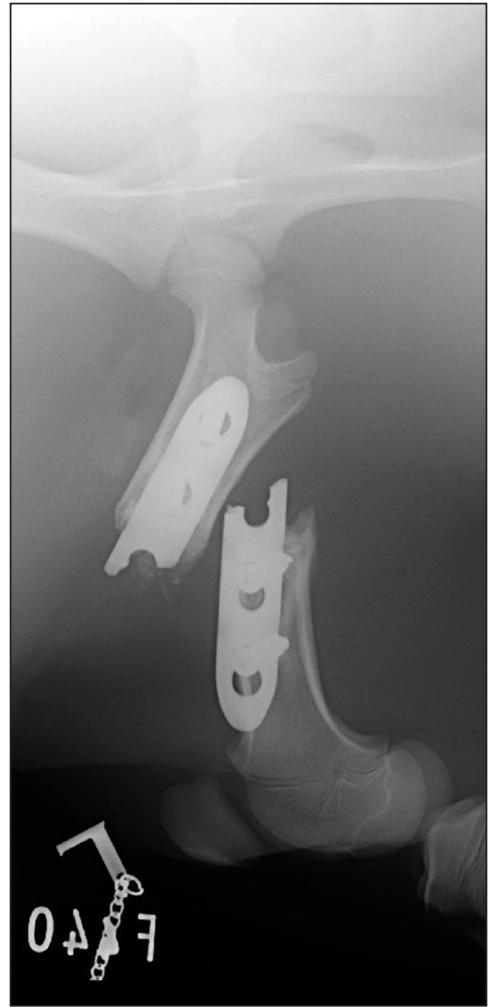

Fig. 4. Fixation of the segmental femoral defect with $4.5 \mathrm{~mm}$ LCP. Plate is broken at the site of the central empty plate hole ( 2 weeks after surgery). 